\title{
Accounting Practices and Its Effects on the Growth of Micro and Small Scale Enterprises: Analysis from Nigeria
}

\author{
Uche Peter Nsoke*, Ndu Marvis Okolo, Grace N. Ofoegbu \\ Department of Accountancy, Faculty of Business Administration, University of Nigeria, Nsukka, Nigeria
}

Received April 23, 2021; Revised June 30, 2021; Accepted July 19, 2021

\section{Cite This Paper in the following Citation Styles}

(a): [1] Uche Peter Nsoke, Ndu Marvis Okolo, Grace N. Ofoegbu, "Accounting Practices and Its Effects on the Growth of Micro and Small Scale Enterprises: Analysis from Nigeria" Universal Journal of Accounting and Finance, Vol. 9, No. 4, pp. 574-587 2021. DOI: 10.13189/ujaf.2021.090405.

(b): Uche Peter Nsoke, Ndu Marvis Okolo, Grace N. Ofoegbu (2021). Accounting Practices and Its Effects on the Growth of Micro and Small Scale Enterprises: Analysis from Nigeria. Universal Journal of Accounting and Finance, 9(4), 574-587. DOI: 10.13189/ujaf.2021.090405.

Copyright@2021 by authors, all rights reserved. Authors agree that this article remains permanently open access under the terms of the Creative Commons Attribution License 4.0 International License

\begin{abstract}
This paper examined the effect of accounting practices on the growth of micro and small enterprises (MSEs) in Nigeria. The study specifically examined the influence of book-keeping and accounting knowledge on the growth of micro and small enterprises as well as the effect of financial management practices on the growth of MSEs in Nigeria. The study adopted survey research design. Micro and small scale enterprises in South-East and South-South geopolitical zones in Nigeria formed the population of the study. The study made use of primary data. Questionnaire was the instrument for data collection. A sample size of 384 was adopted using Bill Godden sample size formula. Proportional stratified random sampling technique was employed to distribute this 384 to MSEs. The data were tested using percentages, mean, and standard deviation, while the hypotheses were tested using regression analysis and analysis of variance. Multicollinearity test was conducted to determine the collinearity of the two independent variables. According to the findings, book-keeping and accounting knowledge as well as financial management practices have significant effect on MSE growth in Nigeria. This finding implies that MSEs will experience continuous growth if they acquire accounting knowledge and apply such knowledge in financial management practices in their business operations. This study will be beneficial to researchers, readers of this work, investors, and intending investors in MSEs in Nigeria. The limitations experienced in the course of this research were the reluctant attitude of some
\end{abstract}

respondents who felt that they might be revealing business secrets to free-riders but later showed full cooperation when convinced it was purely for critical examination of problems of accounting practices affecting MSEs growth in Nigeria and the ability to find out solutions. It recommends government and MSE owners/managers to focus greater attention on the acquisition of book-keeping and accounting knowledge and financial management practices that can constantly lead to MSEs' growth.

Keywords Accounting Practices, Book-Keeping and Accounting Knowledge, Financial Management Practices, Growth of Micro and Small Enterprises, Nigeria

\section{Introduction}

\subsection{Background to the Study}

The value of micro and small enterprises (MSEs) in any economy cannot be overstated. In Nigeria and other countries, micro and small scale enterprises (MSEs) play vital roles in employment and revenue generation. It also leads to the process of industrialization, sustainable economic growth and development [1]; encourages entrepreneurship and employment generation [2]; reduces poverty and contributes to the country's gross domestic product (GDP) [3,4,5]; introduces innovation and 
entrepreneurship skills [6]. Small businesses may not have as big resources as larger companies, yet survival is just as critical to economic development $[7,8]$.

There are tremendous increases in small and micro-scale businesses in Nigeria such as supermarkets, poultry farming, fish farming, animal feed production, kiosks, computer services, carpentry works, barbing and hairdressing salons, sachet water production, productions of soap, powder, pomade, and detergents, restaurants, drug shops, car wash, and the host of others. One common feature of MSEs is the daily provision of business operations for a long period of time. Most of them usually close work at late times of the day.

The ability of MSE operators/managers to acquire the essential bookkeeping and accounting knowledge may have a significant influence on the growth of the MSEs; and the ability to assess the level of growth made in the business operations. In Nigeria for instance, the Central Bank of Nigeria (CBN) in collaboration with Federal and State Governments through the Bank of Industry, Microfinance banks, Centers for entrepreneurship developments, etc established different training centres for those already in existing businesses as well as those starting up new businesses. Some of the areas mapped out for training are record keeping, financial management, book-keeping and accounting skills, preparation of financial reports, feasibility study, etc. Akande [9] posit that entrepreneur skills are the qualities or attributes required for an entrepreneur to start and manage a business successfully in a competitive environment. MSE owners/managers must acquire appropriate book-keeping and accounting knowledge or skills to enable growth in their businesses.

In a related development, financial management is the management of working capital, assets and other resources of the organization in such a way to achieve the enterprise' objectives. Financial management, according to Kilonzo and Ouma[10], 'includes working capital management, investment, finance, accounting information systems, financial reporting, and analysis'. Also, Meredith as cited in ref.[10] maintains that financial management is concerned with all aspects of management that involve finance, including not only the resources and uses of finance in the enterprise, but also the financial implications of investment, production, marketing, or personal decisions, as well as the enterprise's overall performance. Poor management of finance can result to financial loss and, in the worst-case scenario, business failure.

\subsection{Statement of the Problem}

Despite the advantages of micro and small scale enterprises in some developing countries like Nigeria, there are challenges to their growth such as lack of accounting knowledge (Amoako)[11]; lack of managerial accounting skills, technical skills, and improper decision making [12]; careless or poor financial management practices[6,10]; Okafor[13], among others. For MSEs to achieve their objective of growth, acquisition of book-keeping and accounting skills as well as proper financial management practices, etc must be in place.

Inadequate accounting, according to Gohtz as cited in Pavter[14] is one of the top ten causes of small business failure. "You can't run a business if you don't know what's going on with bad numbers or no numbers," adding that "such a firm is flying blind and it happens all the time." He further states that one of the challenges of MSEs is the inability to separate business from own properties. This means lack of knowledge to observe the business entity concept which says that every business entity must have a separate existence from its owners.

MSEs are considered as an essential component of the economy in the United Kingdom (UK), however financial sustainability issues lead to a high failure rate $[15,16,17]$. Due to the competitive environment in which MSEs compete in the United Kingdom, they must be constantly aware of both their internal financial situation and the financial components of their overall business backdrop.

Poor management of enterprise funds could constitute a major setback and business failures. The challenge requires the owners of MSEs to employ an accountant, if he is not, for providing basic accounting functions although the former may lack the resources to do so. Apart from providing basic accounting functions such as auditing, tax matters, budgeting, etc, to owners/managers, the accountants in MSE are required to assist in decision making. Book-keeping and accounting knowledge, as well as financial management practices, are two functions of accounting practices that can lead to the growth of an enterprise if properly maintained, and on the order hand, lead to financial loss and business failure if not guided very well.

\subsection{Objectives to the Study}

The broad objective of this study was to examine accounting practices and its effect on the growth of micro and small enterprises in Nigeria. Specifically, this paper:

i. determines if book-keeping and accounting knowledge of MSE operators have significant influence on the growth of MSEs; and

ii. ascertains whether financial management practices have significant effect on the growth of MSEs in Nigeria.

\subsection{Significance of the Study/Practical Implications}

This research contributes to the body of knowledge about the impact of accounting methods on the growth of micro and small businesses. This is because it allowed testing of the effectiveness of the variables on accounting practices and its effect on the growth of MSEs in Nigeria and came out with findings and recommendations. Other areas this study will be of great significance are to the 
readers of this research work, institutions, individuals and corporate enterprises already in existing businesses, and prospective MSE investors in addressing the factors affecting accounting practices to the growth of MSEs.

\subsection{Limitations of the Study}

Some limitations were encountered in this research work. Many respondents initially showed a reluctant attitude to answer the questionnaire thinking they might be revealing business secrets to free-riders or business competitors but later showed full cooperation when convinced it was purely for critical examination of problems of accounting practices affecting MSEs growth in Nigeria and the ability to find out solutions.

\section{Review of Related Literature and Hypotheses Development}

\subsection{Accounting Practice in MSEs}

Accounting practices are the adoption of all financial and non-financial methods for gathering and recording a business entity's day-to-day financial activities[14]. Thus, MSE accounting practices is defined as the method by which the whole financial activities relating to the enterprise are recorded and the rules and regulations observed. Examples of good accounting practices are:

a) Maintenance of revenue and expenditure records,

b) Keeping records of sales day books,

c) Keeping records of purchases daybooks,

d) Issuing bills to customers immediately goods are supplied to them,

e) Keeping records of all classes of assets,

f) Applying one method of depreciation on the assets,

g) Paying suppliers invoices on the due dates, and

h) Preparation of financial statements at the end of its accounting year etc.

Accounting practices involve the methods established by the management to record, classify, analyze and interpret financial transactions of an organization and with the objectives to achieve the firm's target. One of the advantages of accounting practices is to maintain efficiency in every business activities and to know if the business is growing or not. In Nigeria, the government through the policy of MSMEs 2014 revised made it compulsory for all business enterprises seeking financial assistance from any financial institutions in the country to undergo skills acquisition training where accounting practices such as financial management practices, investment portfolios, decision making etc are taught. Similarly, individuals who see the importance of accounting practices to their business growth undergo training based on the private arrangement with the trainer.
Training on accounting practices especially on skills acquisition and financial management practices have some advantages such as proper planning of business operations, acquisition of bookkeeping and accounting skills, ability to keep accounting records, efficient financial management, proper decision making, prompt production of annual reports, compliance with the Act, and paying the proper amount of tax, among others.

\subsection{Micro and Small Enterprises}

There are no generally accepted definitions of micro and small scale enterprises worldwide. Each country has its definition due to the peculiar nature of MSEs in their respective environments. In Nigeria, the National Policy on Micro Small and Medium Enterprises MSMEs[18] revised gave definition according to size, employees and asset base. It defined micro-enterprises as enterprises operated by financially deprived entrepreneurs with limited or no capacity for credits; less than N1.5 million asset base; and less than Ten (10) employees. It also defined small businesses as an enterprise with asset value less than N50 million but above N1.5 million; and employees between ten (10) and forty-nine(49). Furthermore, the United Kingdom (UK) see micro-enterprises as one with a maximum of nine (9) employees while small business as one with employees between ten and forty-nine (10-49). Micro-enterprises are defined in the United States as small businesses with nine (9) employees or fewer that were established with $\$ 50,000$ or less in start-up capital and do not have access to standard commercial financing. It defined a small business as those with fewer than 50 employees but more than nine (9) (US Small Business Administration)[19].

Furthermore, the United Nations Conference on Trade and Development (UNCTAD) [20] classified micro-enterprise as a business enterprise employing one to five people, and small business as a company employing six to fifty people. The European Union has announced that the idea of micro and small enterprises would be standardized. Companies with less than 10 workers are classified as "Micro," whereas those with fewer than 50 employees are classified as "Small" [21].

The typical micro-enterprises are operated by family members and occasionally school dropouts. Some of the owners employ staffs who assist them in running the business on their behalf. They raise capital through family savings, borrowings, thrift and cooperatives, and the government through granting of free collateral low-interest loans. Most MSE operators operate for a longer period of time daily. Some undertake after-sales services and also adopt credit sales not only to retain their existing customers but also to capture larger market shares which lead to increase in revenue and ultimately growth.

In Nigeria, the government made it mandatory for individuals and registered enterprises to undergo 
mandatory skills acquisition training before accessing credits and other benefits from the government. In addition, some separate individuals and corporate enterprises engage the services of trainers to acquire such skills for their business growth.

\subsubsection{Growth of Micro and Small Enterprises}

Micro and small enterprises play vital roles in our society such as employment generation, poverty alleviation, and economic growth among others[1-5]. Thus, the importance of MSEs cannot be overemphasized. This necessitates that numerous stakeholders should work together to ensure the growth of MSEs. Thus, MSE growth is defined as an increase in a variety of quantitative factors such as revenue, capital, market share, staff count, expansion, and exports, among others. In addition to the Nigerian setting, empirical research has been conducted in many areas of the world to identify the components that lead to the growth of MSEs. However, data from several nations revealed mixed results in terms of the determinants [22]. Although the impact and magnitude of the determinants differ from country to country and firm to firm, there are several common determinants of firm growth, including firm location, financial management practices, initial investment, sector engagement, access to loans, experience in business operations, market availability, proper record keeping, and ICT [22]. Similarly, firms grow faster when it has a business license, located at the traditional market, headed by a male, as well as if it is in manufacturing and service sectors [23]. Business growth is sine qua non to every business organization. It is enhanced when the owner/managers have enough capital, access to finance, customers, have acquired bookkeeping and accounting knowledge/skills or experience, and apply such skills in financial management practices in the organization.

\subsubsection{Book-keeping and Accounting Knowledge of Operators and Growth of MSEs}

Micro and small enterprises (MSEs) play vital roles not only in the generation of employment opportunities but also in stimulating economic growth as well as industrial diversification in the economy. For the MSEs to achieve the above objectives, proper book-keeping and accounting knowledge, accounting controls, etc must be in place. The ability of the operators of MSEs to gain the necessary bookkeeping and accounting knowledge contribute greatly to the growth of the MSEs; able to compete very favourably with both local and foreign competitors.

Experts believed that one of the major reasons MSEs fail in their first five years of operation was due to lack of book-keeping and accounting knowledge[12,19,24]. The idea of book-keeping and accounting by the operators of MSEs enables the MSEs to obtain some advantages such as: ability to keep proper records of their accounting transactions,

- Know whether the business is growing or not and if growing, the rate of growth,

- Enables the operators to manage cash and inventory very well,

- Know the time to hire professionals,

- Be able to prepare the necessary financial reports, - Know the time for expansion and hiring of workers,

- Enables efficient business management, and proper decisions making, etc.

According to Sibanda and Manda [25], a study conducted by South Africa National Research reveals that among the 80 percent of small businesses that fail every year, inexperienced business management, inability to manage costs, non-anticipation of rising costs, and a poorly designed business model are among the financial factors that contributed to their failure. As it is easy to enter MSEs businesses, many people who invest in such MSEs businesses did not have book-keeping and accounting knowledge and, most MSEs operators do not engage themselves in book-keeping and accounting training before venturing into the business[26].

Ref.[12] confirmed that three out of every five firms fail within the first three years of operations, as shown in research carried by the Kenya National Bureau of Statistics. The author stated that some of these causes of business failures are:

- Lack of managerial accounting skills for decision making;

- Lack of technical skills;

- Lack of access to credit, among others.

\subsubsection{Efficient Financial Management practices and Growth of Micro and Small Enterprises}

Ref.[6] posit that acquisition, allocation, and control of financial resources are all parts of MSE financial management processes. It is used to guarantee that the organization's working capital, finances, debtors and creditors, assets, and depreciation are all managed efficiently. It might be viewed as effective working capital management in the organization, ensuring that no private cash is drawn upon business capital. In some cases, MSE owners source their capital from short-term loans or borrowings, etc. However, financial management is the backbone in ensuring the growth of small businesses. Once the finance has been sourced, it requires the involvement of technical skills or the involvement of well trained/professional accountants which MSEs lack the resources to employ.

Financial management techniques include fixed asset management, accounting and financial reporting, working capital management, capital structure management, accounting information systems, and others, according to Reference [6]. Careless financial management may lead to business failures. The failure of MSEs to successfully 
perform broad financial management responsibilities including working capital management (WCM), budgeting, and so on has played a significant role in the global financial crisis [27]. Furthermore, poor or inadequate financial management procedures have been identified as one of the reasons for small business failure (McMahon \& Holmes)[28]; Berrman, 1983 as cited in [13]. In European Union, MSEs make up the vast majority of the business population and contribute two-thirds to European employment [29].

In Nigeria, there are efforts to promote the acquisition of bookkeeping and accounting knowledge as well as training strategies on financial management practices to achieve businesses growth. These they did by providing different training centres for micro, small and medium scale businesses to acquire business skills and financial management practices by registered trainees. Despite the numerous sources of financing made accessible to these firms, MSEs have had difficulty obtaining both short-term and long-term credit from lenders due to fund providers' poor-risk perceptions of small businesses [13]. Even if the loans requested are accessible, fund providers may be reluctant to give loans if there is lack of or inadequate financial information regarding the firm's performance to persuade the lender of the firm's financial situation. The little finance or capital of MSEs, if managed very well could lead to high profit, high market shares, expansion and ultimately growth.

Bookkeeping and accounting knowledge, as well as financial management practices are two functions of accounting practices that can lead to the growth of an enterprise if properly maintained, and on the other hand, lead to financial loss and business failure if not guided very well. In light of the aforementioned factors influencing MSE growth and failure, the following null hypotheses are created to determine the impact of bookkeeping and accounting skills, as well as financial management practices on MSE growth in Nigeria.

a) Book keeping and accounting knowledge of MSE operators have no significant influence on the growth of MSEs, and

b) Financial management practices have no significant effect on the growth of MSEs.

\subsection{Theoretical Consideration}

Efficiency theory was used as the theoretical foundation for this research. A micro and small business owner is someone who starts and runs a business enterprise to achieve personal goals, and sees the enterprise as an extension of their own wants, goals, and personalities. In most cases, the overall objective is to make a steady profit to enable the business to grow. The growth of any business is normally achieved when the managers of such businesses are efficient in their performances. Efficiency, according to Banton[30], is a level of business activity that uses the fewest inputs to provide the most output. To accomplish a given result, it requires using less resources, such as human time and energy to produce a given quantity or quality of output. It is a measurable concept that is calculated by dividing total usable output by total input. It saves resources such as physical materials, energy, and time while attaining the desired result. In general, anything is efficient if no resources (such as materials, energy, or time) are wasted and all processes are optimized. Frederick Winslow Taylor, who investigated how labour was conducted and how it influenced worker productivity in 1909, was the proponent of efficiency theory. Following his research, he argued that increasing productivity might be achieved by optimizing and simplifying occupations. This theory is significant to this research because if resources are not wasted, it will lead to revenue improvement which in turn leads to business growth.

\subsection{Empirical Review}

Extant literature abounds with empirical studies on book keeping and accounting knowledge and financial management practices on the growth of micro and small businesses with findings either mixed or inconclusive. Okoye, Uniamikogbo and Adeusi [31] carried out a study on accounting skills for sustainable entrepreneurial development in Nigeria. Findings indicated that accounting skills have significant benefits for sustainable performance and development. Reference [12] looked into the impact of managerial skills on SMEs on the success and growth of small and medium businesses in Kenya. Findings demonstrated that business owner's or manager's level of training and accounting skills have strong, positive, and significant impact on decision making, and are thus critical for the success, growth, and survival of a small business.

Ilemona [32] evaluated record keeping and accounting as a tool for small business growth in Nigeria. The findings revealed a strong link between effective financial transaction record-keeping and an enterprise's development potential. This indicates that proper record keeping and accounts can be properly kept if the book-keeper has some book-keeping and accounting knowledge. Ademola, James and Olore [33] revealed that the majority of the respondents (i.e. MSEs) do not keep business records and therefore do not even know whether their businesses are growing or not. Also, Boame, Solace and Issaka [34] studied the adoption of accounting practices and their effect on small scale enterprises. The result indicated that lack of accounting knowledge was one of the causes making it often difficult, if not impossible, for MSE operators to separate personal expenses from the business expenditure. On the other hand, ref.[24] studied micro, small, and medium-sized business accounting knowledge, practices, and controls. Majority of MSEs are either extremely educated or familiar with accounting principles and concepts, 
according to the results.

Reference [13] carried out a research on financial management practices on Nigerian small firms. Findings indicated that the efficiency with which small businesses conducts their accounting and financial management duties have favourable and significant impact on their overall performance.

Furthermore, [6] demonstrated that excellent financial management practices provide a backbone to small scale companies' profitability, success, and expansion, while [10] suggested that financial management practices affect SMEs' growth. Ref. [14] examined the accounting practices of SMEs as well as challenges faced by MSEs. The result showed that SMEs keep some accounting records while the challenges have a significant effect on their operations. According to Zuzana and Matej, as cited in [6] careless or poor financial management has been identified as one of the reasons for small business failure, while Kazooba[35] discovered that MSEs have the highest number of non-performing as well as a high number of business closures due to poor financial management. The symptoms of accounting procedures that contribute to small business failure were investigated in ref. [25]. The findings indicated that SMEs frequently fail to follow basic accounting standards, limiting company information that is critical for decision-making.

\section{Methodology}

\subsection{Research Design}

This study adopted a survey research design using a cross-sectional research method. Primary source of data was used. The instrument for data collection was questionnaire. To test the instrument's validity, the initial draft of the questionnaire was given to twenty (20) people from the study group, including some lecturers from our department. Based on their inputs, improvements were made. The improved copies were again administered to another twenty (20) persons from the study group who also made positive inputs. Their inputs together with the researchers' experience on the instrument validation were incorporated in the final copy which is used in carrying out this study. The owner and employee managers were the people given the questionnaire to answer because they were the ones expected to give reliable information about their business operations. Respondents' knowledge was verified by the test of knowledge. The population of the study comprised of all registered and non registered MSEs in the South-East and South-South geopolitical regions of Nigeria. A sample size of 384 was obtained using Bill Godden sample size formula and was distributed to MSEs using proportional stratified random sampling technique. The independent variables were bookkeeping and accounting knowledge (measured by knowledge on accounting principles and concepts) and financial management practices (measured by application of accounting systems, working capital management, financial information management, budgeting, financing, and managerial planning) while the dependent variable was growth of MSEs (measured by revenue improvements).

\subsection{Model Specification}

The hypotheses were tested using linear regression techniques and Analysis of Variance (ANOVA). The independent variables were bookkeeping and accounting knowledge and financial management practices while the dependent variable was growth of MSEs. Thus, the following model equations were used to develop their respective variables.

BAKMO = Book-keeping and accounting knowledge of MSE operators

FMP = Financial management practices

GMSEs $=$ Growth of MSEs

$\mathrm{a}=$ Regression equation intercept

$\mathrm{b}=$ Regression equation coefficient

$\mu=$ error term

Hypothesis one is represented by the equation:

$$
\text { GMSEs }=\mathrm{a}+\mathrm{bBAKMO}+\mu
$$

While hypothesis two is represented by the equation:

$$
\text { GMSEs }=\mathrm{a}+\mathrm{b} \text { FMP }+\mu
$$

\section{Research Findings}

This section presents and analyzes data obtained through the distribution and collation of questionnaire.

Table 1 shows that 196(57\%) respondents were males while $148(43 \%)$ were females. Also, 248 (72.1\%) of the respondents were owner-managers while 96(27.9\%) were employee managers. The information also provided in Table 1 shows the numbers of years respondents operate their current businesses. Thirteen 13(3.8\%) of the respondents has not yet lasted more than one year. Twenty-one people 21(6.1\%), 37(10.8\%), 49(14.2\%), 53(15.4\%), 49(14.2\%), 44(12.8\%), 41(11.9\%) and $31(10.8 \%)$ said they had been in their enterprises for 1-5 years, 6-10 years, $11-15$ years, $16-20$ years, 21-25 years, 26-30 years, 31-35 years, and 36 years and above respectively. This revealed that the majority of responders 53(15.4\%) are in the business for 16-20 years.

Furthermore, the table also showed that none of the respondents' age fell below 18years old. It showed that 44(12.8\%), 79(23.0\%), 99(28.8\%), and 67(19.4\%) fell within the ages of $19-29,30-39,40-49$, and 50-59 respectively while 55(16.0\%) fell within 60 years and above. This showed that the greatest respondents' ages fell within the range of 40-49 years old. 
Table 1. Analysis of information on gender, position in business, number of years in current business, and age brackets of the respondents. (n=344).

\begin{tabular}{|c|c|c|c|}
\hline $\mathrm{S} / \mathrm{N}$ & Variables & N. (Frequency) & Percentages (\%) \\
\hline 1 & $\begin{array}{l}\text { Gender: } \\
\text { Male } \\
\text { Female }\end{array}$ & $\begin{array}{l}196 \\
148\end{array}$ & $\begin{array}{l}57.0 \\
43.0\end{array}$ \\
\hline 2. & $\begin{array}{c}\text { Position in Business: } \\
\text { Owner/manager } \\
\text { Employee/manager }\end{array}$ & $\begin{array}{c}248 \\
96\end{array}$ & $\begin{array}{l}72.1 \\
27.9\end{array}$ \\
\hline 3. & $\begin{array}{c}\text { Number of years in current business: } \\
\text { Less than } 1 \text { year } \\
1-5 \\
6-10 \\
11-15 \\
16-20 \\
21-25 \\
26-30 \\
31-35 \\
36 \text { and above }\end{array}$ & $\begin{array}{l}13 \\
21 \\
37 \\
49 \\
53 \\
49 \\
44 \\
41 \\
37\end{array}$ & $\begin{array}{c}3.8 \\
6.1 \\
10.8 \\
14.2 \\
15.4 \\
14.2 \\
12.8 \\
11.9 \\
10.8\end{array}$ \\
\hline 4 & $\begin{array}{c}\text { Age: } \\
\text { Less than } 18 \text { years } \\
19-29 \\
30-39 \\
40-49 \\
50-59 \\
60 \text { and above }\end{array}$ & $\begin{array}{c}\text { Nil } \\
44 \\
79 \\
99 \\
67 \\
55\end{array}$ & $\begin{array}{c}0 \\
12.8 \\
23.0 \\
28.8 \\
19.4 \\
16.0\end{array}$ \\
\hline
\end{tabular}

Source: Data Analysis, 2021

Table 2. Analysis of information on number of employees, academic qualifications, professional qualifications, and firm registration with corporate affairs commission. ( $\mathrm{n}=344)$.

\begin{tabular}{|c|c|c|c|}
\hline $\mathbf{S} / \mathbf{N}$ & Variables & N. (Frequency) & Percentages (\%) \\
\hline & $\begin{array}{c}\text { Number of employees in your firm: } \\
1-9 \\
10-49 \\
50-299 \\
300 \text { and above } \\
\end{array}$ & $\begin{array}{l}166 \\
178 \\
- \\
-\end{array}$ & $\begin{array}{c}48.3 \\
51.7 \\
- \\
-\end{array}$ \\
\hline 2. & $\begin{array}{c}\text { Highest academic Qualification? } \\
\text { None } \\
\text { FSLC } \\
\text { WASC/SSSC/NECO or its equivalent } \\
\text { NCE/ND or its equivalent } \\
\text { BA/BSC/HNDor its equivalent } \\
\text { MSC/MBA/Ph.D or its equivalent } \\
\end{array}$ & $\begin{array}{c}\text { Nil } \\
36 \\
63 \\
48 \\
143 \\
54\end{array}$ & $\begin{array}{c}- \\
10.5 \\
18.3 \\
13.9 \\
41.6 \\
15.7\end{array}$ \\
\hline 3. & $\begin{array}{c}\text { Professional and other equivalent qualifications } \\
\text { Yes } \\
\text { No }\end{array}$ & $\begin{array}{c}38 \\
306 \\
\end{array}$ & $\begin{array}{l}11.0 \\
89.0\end{array}$ \\
\hline 4. & $\begin{array}{l}\text { Firm Registration with corporate affairs commission: } \\
\text { Yes } \\
\text { No }\end{array}$ & $\begin{array}{l}185 \\
159 \\
\end{array}$ & $\begin{array}{l}53.8 \\
46.2 \\
\end{array}$ \\
\hline
\end{tabular}

Source: Data Analysis, 2021 
Information on table 2 indicated that 166(48.3\%) were in a firm with an employee not more than 9 while 178(51.7\%) were in a firm with employees between 10 and 49. No respondent was in a firm with an employee of 50 and above. This implied that the MSEs sampled were in micro and small scale enterprises.

Results in table I also showed that the majority of the respondents were literate with only 36(10.5\%) having only the FSLC.

Furthermore, 38(11.0\%) of the respondents indicated they had professional and other equivalent qualifications while 306(89.0\%) did not have professional qualifications.

Finally, 185(53.8\%) of the respondents confirmed that their businesses were registered with the Corporate Affairs Commission (CAC) while 159 (46.2\%) said that their firms were not registered with CAC

Table 3 showed that two hundred and ten (210) respondents representing sixty-one (61\%) percent said they have acquired technical, managerial, and or financial training while one hundred and thirty-four (134) respondents representing thirty-nine (39\%) percent affirmed that they have not acquired technical, managerial and or financial training on MSEs.

Table 3. Have you acquired technical, managerial and or financial training on MSEs?

\begin{tabular}{|c|c|c|}
\hline Responses & No of Respondents & Percentages \% \\
\hline Yes & 210 & 61 \\
\hline No & 134 & 39 \\
\hline Total & 344 & 100 \\
\hline
\end{tabular}

Source: Data Analysis, 2021.

Information obtained from table 4 indicates that one hundred and fifty-eight (158) respondents representing forty-six (46\%) percent had a business failure in the past while one hundred and eighty-six (186) respondents representing fifty-four (54) percent claimed that they had never had any business failure in the past.

Table 4. Have you established any business/firm in the past that failed?

\begin{tabular}{|c|c|c|}
\hline Responses & No of Respondents & Percentages \% \\
\hline Yes & 158 & 46 \\
\hline No & 186 & 54 \\
\hline Total & 344 & 100 \\
\hline
\end{tabular}

\section{Source: Data Analysis, 2021.}

Results from table 5 showed that the majority of the respondents being thirty-three (33) representing 20.9\% had their business failure attributed to lack of book-keeping and accounting knowledge. Also, 26 of the respondents said that their past business failure was caused by a lack of proper records of book-keeping and accounts.

Table 6 indicates that 40(11.6\%) respondents affirmed that their revenue in their businesses was highly improved since commencement. Sevent-seven 77(22.4) respondents maintained moderately improved. These implied healthy growth of the businesses. The highest respondents, 133(38.7\%) agreed that their revenue in their businesses slowly improved; Thirty-six 36(10.5\%) of the respondents declined to say anything about their revenue while $58(16.8 \%)$ of the respondents confidentially stated that their businesses did not experience any revenue improvement since commencement. The reasons for non-improvement could be attributed to accounting challenges that are indispensable for every business growth.

Table 5. For those that say yes: the likely factors that contributed to the failure is/are:

\begin{tabular}{|c|c|c|c|}
\hline \multicolumn{2}{|r|}{ Factors } & No of Respondents & Percentages \% \\
\hline a) & Lack of access to bank loans & 11 & 7.0 \\
\hline b) & Lack of book-keeping and accounting knowledge & 33 & 20.9 \\
\hline c) & Inability to separate private from business expanses & 20 & 12.7 \\
\hline d) & High rate of irrecoverable debts & 26 & 16.5 \\
\hline e) & $\begin{array}{l}\text { Lack of experience in business development and decision } \\
\text { making }\end{array}$ & 18 & 11.3 \\
\hline f) & Lack of proper financial planning and management & 21 & 13.2 \\
\hline g) & $\begin{array}{c}\text { lack of proper records of book-keeping and accounts } \\
\text { others }\end{array}$ & $\begin{array}{c}26 \\
3\end{array}$ & $\begin{array}{c}16.5 \\
1.9\end{array}$ \\
\hline & Total & 158 & 100 \\
\hline
\end{tabular}

Source: Data Analysis, 2021.

Table 6. Levels of revenue improvements/growth in business since commencement

\begin{tabular}{|ll|c|c|}
\hline \multicolumn{1}{|c|}{ Responses } & No of Respondents & \multicolumn{2}{c|}{ Percentages } \\
\%
\end{tabular}

Source: Data Analysis, 2021. 
Table 7. Application of knowledge, principles and concepts in business

\begin{tabular}{|c|c|c|c|c|c|c|c|c|}
\hline \multirow[b]{2}{*}{$\begin{array}{l}\text { Accounting } \\
\text { Principles } \\
\text { And Concepts }\end{array}$} & \multicolumn{8}{|c|}{ LEVEL OF KNOWLEDGE } \\
\hline & $\begin{array}{c}\text { Very } \\
\text { knowledgeable } \\
\text { (5) } \\
\end{array}$ & $\begin{array}{c}\text { Moderately } \\
\text { knowledgeable } \\
(4) \\
\end{array}$ & $\begin{array}{c}\text { Knowledgeable } \\
\text { (3) }\end{array}$ & $\begin{array}{c}\text { Low } \\
\text { knowledgeable } \\
\text { (2) }\end{array}$ & $\begin{array}{c}\text { None } \\
\text { knowledgeable } \\
\text { (1) }\end{array}$ & Total & mean & ST.D \\
\hline $\begin{array}{c}\text { Historical } \\
\text { cost }\end{array}$ & 94 & 86 & 62 & 57 & 45 & 344 & 3.37 & 1.38 \\
\hline $\begin{array}{c}\text { Entity } \\
\text { concept }\end{array}$ & 63 & 64 & 69 & 73 & 75 & 344 & 2.90 & 1.41 \\
\hline $\begin{array}{c}\text { Going } \\
\text { concern }\end{array}$ & 93 & 82 & 69 & 51 & 49 & 344 & 3.35 & 1.39 \\
\hline Relevance & 46 & 51 & 72 & 83 & 92 & 344 & 2.64 & 1.37 \\
\hline Periodicity & 73 & 70 & 68 & 69 & 64 & 344 & 3.06 & 1.34 \\
\hline Completeness & 61 & 69 & 72 & 72 & 70 & 344 & 2.94 & 1.39 \\
\hline Consistency & 63 & 68 & 68 & 70 & 75 & 344 & 2.92 & 1.42 \\
\hline $\begin{array}{l}\text { Revenue } \\
\text { recognition }\end{array}$ & 59 & 64 & 69 & 75 & 77 & 344 & 2.86 & 1.40 \\
\hline $\begin{array}{l}\text { Expense } \\
\text { recognition }\end{array}$ & 60 & 65 & 68 & 74 & 77 & 344 & 2.88 & 1.41 \\
\hline $\begin{array}{c}\text { Total/Av. } \\
\text { mean }\end{array}$ & 682 & 694 & 681 & 692 & 691 & 3440 & & 0.03 \\
\hline
\end{tabular}

Source: Data Analysis, 2021

Table 8. Application of Selected Financial Management Practices

\begin{tabular}{|c|c|c|c|c|c|c|c|c|}
\hline \multirow[b]{2}{*}{$\begin{array}{c}\text { Financial management } \\
\text { Practices }\end{array}$} & \multicolumn{8}{|c|}{ LEVEL OF KNOWLEDGE } \\
\hline & $\begin{array}{c}\text { Highly } \\
\text { Applied } \\
\text { (5) }\end{array}$ & $\begin{array}{c}\text { Moderately } \\
\text { Applied } \\
\text { (4) } \\
\end{array}$ & $\begin{array}{c}\text { Applied } \\
\text { (3) }\end{array}$ & $\begin{array}{c}\text { Unfairly } \\
\text { Applied } \\
\text { (2) }\end{array}$ & $\begin{array}{c}\text { None } \\
\text { Applied } \\
\text { (1) } \\
\end{array}$ & Total & Mean & ST.D \\
\hline $\begin{array}{l}\text { i Accounting systems: } \\
\text { Financial records } \\
\text { Cost accounting system } \\
\text { Computerized accounting system }\end{array}$ & $\begin{array}{c}111 \\
57 \\
56\end{array}$ & $\begin{array}{l}84 \\
58 \\
61\end{array}$ & $\begin{array}{l}58 \\
60 \\
66\end{array}$ & $\begin{array}{l}50 \\
78 \\
79\end{array}$ & $\begin{array}{l}41 \\
91 \\
82\end{array}$ & $\begin{array}{l}344 \\
344 \\
344\end{array}$ & $\begin{array}{l}3.51 \\
2.74 \\
2.80\end{array}$ & $\begin{array}{l}1.38 \\
1.43 \\
1.41\end{array}$ \\
\hline $\begin{array}{l}\text { ii Working capital Management: } \\
\text { Cash and Bank Management } \\
\text { Inventory Management } \\
\text { Debit Sales Management } \\
\text { Credit Purchases Management } \\
\text { Management of bad debts } \\
\text { Management of discounts } \\
\end{array}$ & $\begin{array}{c}123 \\
81 \\
102 \\
103 \\
56 \\
94 \\
\end{array}$ & $\begin{array}{l}90 \\
77 \\
81 \\
79 \\
67 \\
80 \\
\end{array}$ & $\begin{array}{l}87 \\
70 \\
61 \\
68 \\
70 \\
71 \\
\end{array}$ & $\begin{array}{l}32 \\
66 \\
53 \\
50 \\
70 \\
62 \\
\end{array}$ & $\begin{array}{l}12 \\
50 \\
47 \\
44 \\
71 \\
37 \\
\end{array}$ & $\begin{array}{l}344 \\
344 \\
344 \\
344 \\
344 \\
344 \\
\end{array}$ & $\begin{array}{l}3.81 \\
3.21 \\
3.40 \\
3.43 \\
2.82 \\
3.38 \\
\end{array}$ & $\begin{array}{l}1.12 \\
1.38 \\
1.40 \\
1.38 \\
1.37 \\
1.34 \\
\end{array}$ \\
\hline $\begin{array}{c}\text { iii Financial Information } \\
\text { Management: } \\
\text { Preparation of financial } \\
\text { statements } \\
\text { Audit of financial statements } \\
\text { Use of financial ratios } \\
\text { Software storage } \\
\end{array}$ & $\begin{array}{l}44 \\
40 \\
38 \\
56 \\
\end{array}$ & $\begin{array}{l}59 \\
47 \\
40 \\
61 \\
\end{array}$ & $\begin{array}{l}69 \\
66 \\
58 \\
65 \\
\end{array}$ & $\begin{array}{l}75 \\
\\
81 \\
92 \\
79 \\
\end{array}$ & $\begin{array}{c}97 \\
110 \\
116 \\
83 \\
\end{array}$ & $\begin{array}{l}344 \\
344 \\
344 \\
344 \\
\end{array}$ & $\begin{array}{l}2.65 \\
\\
2.49 \\
2.40 \\
2.79 \\
\end{array}$ & $\begin{array}{l}1.38 \\
1.37 \\
1.35 \\
1.41 \\
\end{array}$ \\
\hline $\begin{array}{c}\text { ivBudgeting practices: } \\
\text { Cash budget } \\
\text { Capital budget } \\
\text { Sales budge } \\
\text { Profit budget } \\
\text { Production budget } \\
\text { Operational budget } \\
\end{array}$ & $\begin{array}{l}59 \\
64 \\
67 \\
80 \\
83 \\
53 \\
\end{array}$ & $\begin{array}{l}58 \\
69 \\
69 \\
73 \\
78 \\
62 \\
\end{array}$ & $\begin{array}{l}56 \\
72 \\
77 \\
70 \\
63 \\
70 \\
\end{array}$ & $\begin{array}{l}77 \\
76 \\
68 \\
62 \\
61 \\
73 \\
\end{array}$ & $\begin{array}{l}94 \\
63 \\
63 \\
59 \\
59 \\
86 \\
\end{array}$ & $\begin{array}{l}344 \\
344 \\
344 \\
344 \\
344 \\
344 \\
\end{array}$ & $\begin{array}{l}2.74 \\
2.99 \\
3.03 \\
3.15 \\
3.19 \\
2.78 \\
\end{array}$ & $\begin{array}{l}1.45 \\
1.38 \\
1.38 \\
1.41 \\
1.42 \\
1.40 \\
\end{array}$ \\
\hline $\begin{array}{c}\text { v Financing Management: } \\
\text { Internally generated cash sources } \\
\text { Borrowing sources } \\
\text { Both internally generated and } \\
\text { borrowing sources }\end{array}$ & $\begin{array}{l}77 \\
37 \\
63\end{array}$ & $\begin{array}{l}74 \\
44 \\
68\end{array}$ & $\begin{array}{l}68 \\
71 \\
70\end{array}$ & $\begin{array}{l}65 \\
86 \\
71\end{array}$ & $\begin{array}{c}60 \\
106 \\
72\end{array}$ & $\begin{array}{l}344 \\
344 \\
344\end{array}$ & $\begin{array}{l}3.13 \\
2.48 \\
\\
2.94\end{array}$ & $\begin{array}{l}1.41 \\
1.33 \\
1.42\end{array}$ \\
\hline $\begin{array}{l}\text { vi Managerial Planning: } \\
\text { Financial Planning } \\
\text { Marketing planning } \\
\text { Wages/salaries planning } \\
\text { Investment planning } \\
\text { Expansion planning } \\
\text { Personal planning } \\
\text { Performance evaluation }\end{array}$ & $\begin{array}{l}81 \\
74 \\
77 \\
69 \\
74 \\
81 \\
78 \\
\end{array}$ & $\begin{array}{l}76 \\
70 \\
72 \\
64 \\
70 \\
73 \\
71 \\
\end{array}$ & $\begin{array}{l}67 \\
67 \\
69 \\
63 \\
68 \\
66 \\
65 \\
\end{array}$ & $\begin{array}{l}64 \\
68 \\
66 \\
70 \\
67 \\
63 \\
66 \\
\end{array}$ & $\begin{array}{l}56 \\
65 \\
60 \\
78 \\
65 \\
61 \\
64 \\
\end{array}$ & $\begin{array}{l}344 \\
344 \\
344 \\
344 \\
344 \\
344 \\
344 \\
\end{array}$ & $\begin{array}{l}3.18 \\
3.06 \\
3.12 \\
2.93 \\
3.06 \\
3.15 \\
3.10 \\
\end{array}$ & $\begin{array}{l}1.40 \\
1.42 \\
1.41 \\
1.38 \\
1.42 \\
1.43 \\
1.43 \\
\end{array}$ \\
\hline Average & & & & & & & 3.02 & 0.03 \\
\hline
\end{tabular}

Source: Data Analysis, 2021 
Results in Table 7 showed that historical cost, going concern, and periodicity with a mean of 3.37, 3.35, and 3.06 respectively implied that the respondents have knowledge on these aspects of accounting principle and concepts. Also, the respondents did not have knowledge about entity concepts, relevance, completeness, consistency, revenue recognition, and expense recognition with a mean of 2.9, 2.64, 2.94, 2.92, 2.86, and 2.88 respectively. The standard deviation of 0.03 suggested that the respondents' opinions were nearly identical.

Results in Table 8 showed the mean of the six components of financial management practices. The mean of accounting systems is 3.02. This implied that MSEs applied accounting systems in their business operations. The mean of working capital management is 3.34. This means that it is moderately applied. Financial information management has a mean of 2.58. It signifies that it was unfairly applied. Others are budgetary practices and financing management with a mean of 2.98 and 2.85 respectively. These import that those variables were unfairly applied. Finally, managerial planning with a mean of 3.09 denotes that it is applied in business operations. The standard deviation of 0.03 indicated that the respondents' opinions were not that dissimilar.

\subsection{Test of Hypotheses}

\subsubsection{Hypothesis one}

$\mathrm{Ho}_{1}$ : Book-Keeping and accounting knowledge of MSE operators have no significant influence on the growth of MSES

$\mathrm{Hi}_{1}$ : Book-Keeping and accounting knowledge of MSE operators have significant influence on the growth of MSES

Table 9. Model Summary

\begin{tabular}{|c|c|c|c|c|c|}
\hline Model & R & R Square & $\begin{array}{c}\text { Adjusted R } \\
\text { Square }\end{array}$ & $\begin{array}{c}\text { Std. Error of } \\
\text { the Estimate }\end{array}$ & $\begin{array}{c}\text { Durbin- } \\
\text { Watson }\end{array}$ \\
\hline 1 & $.954^{\mathrm{a}}$ & .910 & .910 & .33916 & .435 \\
\hline
\end{tabular}

a. Predictors: (Constant), Book-keeping and accounting knowledge of MSE operators

b. Dependent Variable: Growth of MSEs

Table 10. ANOVA

\begin{tabular}{|c|c|c|c|c|c|c|}
\hline \multicolumn{2}{|c|}{ Model } & $\begin{array}{c}\text { Sum of } \\
\text { Squares }\end{array}$ & Df & $\begin{array}{c}\text { Mean } \\
\text { Square }\end{array}$ & F & Sig. \\
\hline \multirow{2}{*}{1} & Regression & 397.719 & 1 & 397.719 & $\begin{array}{c}3457.6 \\
25\end{array}$ & $.000^{\mathrm{b}}$ \\
\cline { 2 - 7 } & Residual & 39.339 & 342 & .115 & & \\
\cline { 2 - 7 } & Total & 437.058 & 343 & & & \\
\hline
\end{tabular}

a. Dependent Variable: Growth of MSEs

b. Predictors: (Constant), Book-keeping and accounting knowledge of MSE operators
Table 11. Coefficients

\begin{tabular}{|c|c|c|c|c|c|c|}
\hline & \multirow{2}{*}{ Model } & \multicolumn{2}{|c|}{\begin{tabular}{|c|} 
Unstandardized \\
Coefficients \\
\end{tabular}} & \multirow{2}{*}{\begin{tabular}{|c|}
$\begin{array}{r}\text { Standardized } \\
\text { Coefficients }\end{array}$ \\
Beta \\
\end{tabular}} & \multirow[t]{2}{*}{$\mathrm{T}$} & \multirow[t]{2}{*}{ Sig. } \\
\hline & & B & $\begin{array}{l}\text { Std. } \\
\text { Error }\end{array}$ & & & \\
\hline & (Constant) & .085 & .037 & & 2.333 & .020 \\
\hline 1 & \begin{tabular}{|c|} 
Book-keeping \\
and accounting \\
knowledge of \\
MSE operators
\end{tabular} & .944 & .016 & .954 & 58.802 & .000 \\
\hline
\end{tabular}

a. Dependent Variable: Growth of MSEs

$$
\begin{aligned}
& \mathrm{R} \quad=0.954 \\
& \mathrm{R}^{2}=0.910 \\
& \mathrm{~F} \quad=3457.625 \\
& \mathrm{~T}=58.802 \\
& \mathrm{DW}=0.435
\end{aligned}
$$

\section{Interpretation:}

Tables 9, 10, and 11 revealed that the regression sum of squares (397.719) on table 9 is greater than the residual sum of squares (39.339) on the same table. This means that the model doesn't explain a significant percentage of the variance in the dependent variable. The significance value of the F statistics is less than 0.05 , indicating that the variation explained by the model is not due to chance.

The correlation coefficient $\mathrm{R}$, which in table 9 has a value of 0.954 , suggests that there is a positive link between MSE operators' bookkeeping and accounting expertise and the rise of MSEs. The coefficient of determination, $\mathrm{R}$ square, reveals that the model can explain 91.0 percent of the growth of MSEs.

The error of estimate for the linear regression model is modest, with a value of around 0.33916. There is no autocorrelation based on the Durbin Watson statistics of 0.435 , which is less than 2 .

The book-keeping and accounting knowledge of MSEoperators coefficient of 0.954 suggests a statistically significant positive correlation between book-keeping and accounting knowledge of MSE operators and MSE growth $(t=58.802)$.Therefore, there is no reason to accept the null hypothesis while the alternative hypothesis accordingly accepted. As a result, we conclude that book keeping and accounting knowledge of MSE operators have significant influence on the growth of MSEs.

\subsubsection{Hypothesis two}

$\mathbf{H o}_{2}$ : Financial management practices have no significant effect on the growth of MSEs.

$\mathbf{H i}_{2}$ : Financial management practices have significant effect on the growth of MSEs. 
Table 12. Model Summary

\begin{tabular}{|c|c|c|c|c|c|}
\hline Model & $\mathrm{R}$ & R Square & $\begin{array}{c}\text { Adjusted R } \\
\text { Square }\end{array}$ & $\begin{array}{c}\text { Std. Error } \\
\text { of the } \\
\text { Estimate }\end{array}$ & $\begin{array}{c}\text { Durbin-Wats } \\
\text { on }\end{array}$ \\
\hline 1 & $.871^{\mathrm{a}}$ & .758 & .757 & .53040 & .430 \\
\hline
\end{tabular}

a. Predictors: (Constant), Financial management practices

b. Dependent Variable: Growth of MSEs

Table 13. ANOVA $^{\mathrm{a}}$

\begin{tabular}{|c|c|c|c|c|c|c|}
\hline \multicolumn{2}{|c|}{ Model } & $\begin{array}{c}\text { Sum of } \\
\text { Squares }\end{array}$ & Df & $\begin{array}{c}\text { Mean } \\
\text { Square }\end{array}$ & F & Sig. \\
\hline \multirow{4}{*}{1} & Regression & 301.225 & 1 & 301.225 & 1070.732 & $.000^{\text {b }}$ \\
\cline { 2 - 7 } & Residual & 96.214 & 342 & .281 & & \\
\cline { 2 - 7 } & Total & 397.439 & 343 & & & \\
\hline
\end{tabular}

a. Dependent Variable: Growth of MSEs

b. Predictors: (Constant), Financial management practices

Table 14. Coefficients ${ }^{\mathrm{a}}$

\begin{tabular}{|c|c|c|c|c|c|c|}
\hline \multicolumn{2}{|c|}{ Model } & \multicolumn{2}{|c|}{$\begin{array}{c}\text { Unstandardized } \\
\text { Coefficients }\end{array}$} & $\begin{array}{c}\text { Standardized } \\
\text { Coefficients }\end{array}$ & \multirow{2}{*}{$\mathrm{T}$} & Sig. \\
\cline { 2 - 5 } & $\mathrm{B}$ & Std. Error & Beta & & \\
\hline \multirow{2}{*}{1} & \begin{tabular}{c} 
(Constant) \\
\cline { 2 - 5 }
\end{tabular} & .240 & .057 & & 4.213 & .000 \\
\hline
\end{tabular}

a. Dependent Variable: Growth of MSEs

$\mathrm{R} \quad=0.871$

$\mathrm{R}^{2}=0.758$
$\mathrm{T} \quad=32.722$

$\mathrm{F} \quad=1070.732$

$\mathrm{DW}=0.430$

\section{Interpretation:}

Tables 12, 13 and 14 show that the regression sum of squares (301.225) is greater than the residual sum of squares (96.214), indicating that the model does not account for more of the variance in the dependent variable. The significant value of the F statistics $(0.000)$ is less than 0.05 , indicating that the variation explained by the model is not due to chance.

Table 14 demonstrates that, based on the correlation coefficient of 0.871 , there is a positive relationship between financial management techniques and MSE growth. The R square, or the coefficient of determination,.

The error of estimate for the linear regression model is modest, with a value of around.33916. There is no autocorrelation based on the Durbin Watson statistics of 0.430 , which is less than 2 .

The statistically significant positive link between financial management techniques and MSE development ( $\mathrm{t}$ $=32.722$ ) is indicated by the coefficient of 0.871 . As a result, the study's evidence for rejecting the null hypothesis and accepting the alternative hypothesis is compelling. As a result, the study concludes that financial management practices have significant effect on the growth of MSEs.

Table 15. Model Summary

\begin{tabular}{|c|c|c|c|c|c|}
\hline Model & $\mathbf{R}$ & R Square & Adjusted R Square & Std. Error of the Estimate & Durbin-Watson \\
\hline 1 & $.922^{\mathrm{a}}$ & .849 & .698 & 35.84233 & 2.661 \\
\hline
\end{tabular}

Tables 16. Collinearity Diagnostics

\begin{tabular}{|c|c|c|c|c|c|c|c|c|}
\hline \multicolumn{9}{|c|}{ Coefficients } \\
\hline \multirow{2}{*}{\multicolumn{2}{|c|}{ Model }} & \multicolumn{2}{|c|}{ Unstandardized Coefficients } & \multirow{2}{*}{$\begin{array}{c}\begin{array}{c}\text { Standardized } \\
\text { Coefficients }\end{array} \\
\text { Beta } \\
\end{array}$} & \multirow{2}{*}{$\mathbf{T}$} & \multirow{2}{*}{ Sig. } & \multicolumn{2}{|c|}{ Collinearity Statistics } \\
\hline & & B & Std. Error & & & & Tolerance & VIF \\
\hline \multirow{3}{*}{1} & (Constant) & 255.977 & 103.316 & & 2.478 & .132 & & \\
\hline & $\begin{array}{c}\text { Financial management } \\
\text { practices }\end{array}$ & 1.746 & 2.428 & .730 & .719 & .547 & .073 & 13.680 \\
\hline & $\begin{array}{c}\text { Book-keeping and accounting } \\
\text { knowledge of MSE }\end{array}$ & .259 & 1.335 & .197 & .194 & .864 & .073 & 13.680 \\
\hline
\end{tabular}

Table 17. Collinearity Diagnostics

\begin{tabular}{|c|c|c|c|c|c|c|}
\hline \multirow{2}{*}{ Model } & \multirow{2}{*}{ Dimension } & Eigenvalue & Condition Index & (Constant) & $\begin{array}{c}\text { Financial management } \\
\text { practices }\end{array}$ & $\begin{array}{c}\text { Book-keeping and accounting } \\
\text { knowledge of MSE }\end{array}$ \\
\hline \multirow{3}{*}{1} & 1 & 2.883 & 1.000 & .00 & .00 & .00 \\
\cline { 3 - 7 } & 2 & .114 & 5.033 & .11 & .00 & .06 \\
\cline { 2 - 6 } & 3 & .004 & 28.238 & .88 & 1.00 & .94 \\
\hline
\end{tabular}


Table 18. Residuals Statistics

\begin{tabular}{|c|c|c|c|c|c|}
\hline & Minimum & Maximum & Mean & Std. Deviation & N \\
\hline Predicted Value & 21.1158 & 174.5650 & 85.2000 & 60.13626 & 5 \\
\hline Residual & -27.83113 & 36.43116 & .00000 & 25.34435 & 5 \\
\hline Std. Predicted Value & -1.066 & 1.486 & .000 & 1.000 & 5 \\
\hline Std. Residual & -.776 & 1.016 & .000 & .707 & 5 \\
\hline
\end{tabular}

The multicollinearity tests (conditional Index, Variance Inflation factors and variance proportions) strongly proves that the independent variables -financial management practices and book-keeping and accounting knowledge are not collinear to the point of affecting their functions as exogenous variables.

The residual diagnostics as reported above supports the collinearity diagnostics in overriding the likelihood of multicollinearity and other intervening diagnostic problems in the estimated model. Notably, the Durbin Watson statistics which is in the region of 2, rules out every suspicion of a first-order autocorrelation.

\section{Discussion}

The result from hypothesis one revealed that book-keeping and accounting knowledge of MSE operators have significant influence on the growth of MSEs. This implied that the more MSE operators/managers acquaint themselves with bookkeeping and accounting knowledge and skills the more it assist them in the proper application of accounting practices for business growth. This result is similar to the findings from $[29,12,32]$. On the other hand, the study is not in line with the result from[26].

Furthermore, the outcome of hypothesis two demonstrated that financial management practices have significant effect on MSE growth. This implies that efficient use of working capital and other resources enhance growth of business organization. This result is in agreement with the results of research work from $[13,6,10]$. Since both studies virtually agreed with the findings of other studies, this showed that the efficiency theory is supported. The theory states that optimal use of a firm's resources enhances the growth of an enterprise.

\section{Conclusion and Recommendation}

Book keeping and accounting knowledge of MSE operators have significant influence on the growth of micro and small enterprises. Furthermore, financial management practices have significant effect on the growth of MSEs in Nigeria. These implied that the acquisition of bookkeeping and accounting knowledge as well as adequate financial management practices in business operations will lead to growth of the enterprise. Thus, in line with the findings, the government and the operators/managers and prospective investors in MSEs should focus attention on the acquisition of book-keeping and accounting knowledge and adequate financial management practices that lead to growth of MSEs.

\section{REFERENCES}

[1] Ariyo, D. "Small Firms are the Backbone of the Nigerian Economic”. African Economic Analysis, 2005. Retrieved from http://africaeconomicanalysis.org/articles/gen/smallht m. htgml

[2] Ogujiuba, K.K., Ohuche, F.K., \& Adenuga, A.O. "Credit Availability to Small and Medium Scale Enterprises in Nigeria: Importance of New Capital base for BankingBackground and Issues”. AIAE, BPS Project, Ebonyi State University and Central Bank of Nigeria working papers, Es, E51, G2, G2, 2004. Retrieved from: http://www.credit_Availability_to_small_and_Medium_Sc ale_Ente.

[3] Audretsch, D.B. "Dynamic Role of Small Firms: Evidence from the US”. World Bank Institute, 2010, 2001-2037.

[4] Okafor, R.G. (2018, September 13). "Un-Marketed Output of the Household Economy: A Missing link in the Nigerian System of National Accounts" [Conference session]. $142^{\text {nd }}$ inauguration lecture of the University of Nigeria, Nsukka, Nigeria.

[5] Taiwo, A., Ayodeji, A.M., \& Yusuf, A.B. "Impact of Small and Medium Enterprises on Economic Growth and Development”. American Journal of Business and Management vol.1, no.1, pp.18-22, 2012

[6] Yohanes, D., Debela K.L, \& Shibru, W. (2018). "Effect of Financial Management Practices on Profitability of Small-Scale Enterprises: Case Study: Hawassa City Administration, Ethiopia”. IOSR Journal of Business and Management. vol. 20, no. 6, pp. 39-45, 2018.

[7] Bamham, H., \& He, Y. "Exploring the Relationship between Accounting Professionals and Small and Medium Enterprises (SMEs)”. Journal of Business and Economic Research.vol.12, no. 4, pp. 209-214, 2014. Retrieved from: www.cluteinstitute.com/

[8] Kamyabi, Y., \& Devi, S. "Accounting Outsourcing and Firm Performance in Iranian SMEs”. International Journal of Economic and Finance. vol. 3, no.4, pp. 169-181, 2014. Doi:10.5539/ijef.v3n4pi81 
[9] Akande, O.O. “Accounting Skills as a Performance Actor for Small Business in Nigeria”. Journal of Emerging Trends in Economics and Management Studies”. vol. 2, no. 5, 2011

[10] Kilonzo, J. M., \& Ouma, D. "Financial Management Practices on Growth of Small and Medium Enterprises: A case of Manufacturing Enterprises in Nairobi County, Kenya,” 10SR Journal of Business and Management, vol. 17, no. 8, pp. 65-77, 2015

[11] Amoako, G.K. "Accounting Practices of SMEs. A Case Study of Kumasi Metropolis in Ghana”. International Journal of Business and Management. vol. 8, no. 24, pp. 73-83, 2013

[12] Mbogo, M. "Influence of Managerial Accounting Skills on SMEs on the Success and Growth of Small and Medium Enterprises in Kenya”. Journal of language, Technology and Entrepreneurship in Africa. vol. 3, no. 1, 2011

[13] Okafor, R.G. "Financial Management Practices of Small Firms in Nigeria: Emerging Tasks for the Accountant," European Journal of Business and Management, vol. 4, no. 19, 2012

[14] Pavtar, A.A. “Accounting Practices of SMEs: Challenges and Effects: A Survey of SMEs in Makurdi Metropolis, Benue State, Nigeria," World Journal of Finance and Investment Research, vol. 2, no.1, 2017, Accessed from: www.iiardpub.org

[15] Broccardo L. "Management Accounting Systems in Italian SMEs: Some Evidences and Implications,” Journal of Advance in Management and Applied Economics, vol. 4, no.4, pp. 1-16, 2014

[16] European Commission. "Evaluation of the User Guide to the SME Definition. Directorate General for Enterprises and Industry," 2015, Retrieved from: http://ec.europa.eu/D ocsRoom/documents/5766/attachments/1/translations/en/re ndingms/native

[17] Tripathi, V. M. “The Management Accounting Needs of Small Enterprises and the Role of Small Accounting Practices," [Doctoral thesis, Open University, United Kingdom], 2017, Retrieved from: http://oro.open.ac.uk/49 022/, DOI: https://doi.org/10.21954/ou.ro.0000bf7e

[18] Nigerian National Policy on Micro, Small and Medium Enterprises (MSMEs) (2014). Retrieved from: http://www.NARIONAL-POLICY-ON-MSMESNEW(1)pdf.

[19] US Small Business Administration, "Business trends", 2014, Retrieved from: http://www.sba.gov/content/small-b usiness-trends

[20] United Nations Conference on Trade and Development (UNCTAD), "Accounting by Small and Medium-Sized Enterprises,” 2000, Retrieved from:https://unctad.org>tdr2 000_en pdf

[21] European Commission, "Commission Recommendation Concerning the Definition of Micro, Small and Medium Sized Enterprises”. Official Journal of the European. 20 May, 2005

[22] Meressa, H.A. "Growth of Micro and Small Scale Enterprises and its Driving Factors: Empirical Evidence from Entrepreneurs in Emerging Region of Ethiopia”. Journal of Innovation and Entrepreneurship. Vol. 9, no 11,
2020.

[23] Gebreeyesus, M. "Growth of Micro Enterprises: Empirical from Ethiopia”. Ethiopian Development Research Institute (EDRI). Retrieved from https://www.researchgate. net/publication/228457234_Growth_of_Micro_Enterprises _Empirical_from_Ethiopia

[24] Dawuda, A., \& Azeko, I. "An Assessment of Financial Records Keeping Behavior of Small Scale Business in Ghana: A Case Study of Bolgatanga Municipality”. International Journal of Finance and Accounting. vol. 4, no. 3, pp. 187-194, 2015. DOI: 10.5923/j.ijfa.20150403.06

[25] Sibanda, J.J., \& Manda, D.C. "Symptoms of Accounting Practices that Contributes to Small Business Failures in South Africa,” 2016, Retrieved from: PPM=2016-04cont-s ibanda (1). Pdf. DOI: http://dx.doi.org/10.21511/ppm. 14(4-1).2016.08.

[26] Ibara, V.C., \& Rodrigo, M.V. “Accounting Knowledge, Practices, and Controls of Micro, Small and Medium Enterprises: Evidence from the Philippines”. Journal of Accounting and Taxation, vol. 7, no. 2, pp. 83 - 96, 2015

[27] Osisioma, B.C. "Global Financial Crisis: Impact on the Changing Face of Accountancy Profession". Frontiers lectures series. Nnamdi Azikiwe University, Awka. 2010.

[28] McMahon, R.G.P., \& Holmes, S. "Small Business Financial Management Practices in North America: A Literature review”. Journal of Small Business Management. vol. 29, no. 2, pp. 19-29, 1991

[29] Wiedemann, D. "Characteristics of Management Accounting in Small and Medium-Sized Enterprises: Case: Rantalinna Oy”. 2014. Retrieved from https:/www.semanticscholar. org/paper/characteristics-ofmanagement-accounting-in-small-Wiedemann/ 097380690c47302583819c0b3d602d96ecc.494f.

[30] Banton, C. "Efficiency Definition". 2020, Retrieved from https://www.investopedia. com/terms/e/efficiency-asp

[31] Okoye, E.I., Uniamikogbo, E. \& Adeusi, A.S. “Accounting Skills for Sustainable Entrepreneurial Development: A study of Selected Small and Medium Scale Enterprises in Edo State, Nigeria”. International Conference on African Entrepreneurship and Innovation for Sustainable Development, 2017, Retrieved from: https//www.ACCOUNTINGSKILLSFORSUSTAINABLE ENTREPRENEURIALDEVELOPMENT.

[32] Ilemona, A. S. "Record Keeping and Accounts as a Tool for Growth of Small Scale Enterprises in Nigeria economy”. Multidisciplinary Journal of Empirical Research, vol. 9, no. 1, 2011

[33] Ademola, G. O., James, S. O., \& Olore, I. "The Roles of Record Keeping in the Survival and Growth of Small Scale Enterprises in Ijumu Local Government Area of Kogi State”. Global Journal of Management and Business Research, vol. 12, no.13, pp. 54-66, 2012

[34] Boame, I., Solace, K., \& Issaka, S. "Adoption of Accounting Practices and its Effects on Small Scale Enterprises: Financial Perspective and Satchet Water Producers in Northern Region of Ghana”. Research Journal of Finance and Accounting, vol. 5, no. 17, 2014 
[35] Kazooba, C.T. "Causes of Small Business Failure in Uganda: A Case Study from Bushenyi and Mbarara towns”. 2006, Retrieved from: https://www.researchgate.net/public
ation/291863118_Causes_of_small_business_failure_in_U ganda_A_case_study_from_Bushenyi_and_Mbarara_town s. 